\title{
IMPROVEMENT OF TURNING AND DRILLING BY ULTRASONIC ASSISTANCE
}

\author{
Celaya, A.; PujanA, J.; Lopez De LaCAlle, L.N.; \\ RIVERO, A. \& CAMPA, F.J.
}

Abstract: In this work, the advantages and drawbacks of ultrasonic assisted turning and drilling have been investigated. The effect of tool vibration on surface quality has been studied in turning of mild steel. Several experiments have been performed changing the cutting speed, feed and depth of cut, to study how the influence of the ultrasonic vibration on the surface roughness varies depending on the cutting conditions. The results obtained show that ultrasonic vibration can improve the surface quality.

Vibration has been also applied on the drilling process of Ti6Al4V workpiece samples. The ultrasonic assisted drilling process has been studied monitoring feed forces and temperature on the drill tip using infrared radiation thermometry. It is shown that ultrasonic assisted drilling achieves lower feed forces and higher process temperatures compared to conventional drilling. Vibration amplitude variation has also been studied resulting in higher force reductions and higher temperature increments as vibration amplitude increases.

Key words: ultrasonic vibration; turning; drilling; mild steels; Ti6Al4V
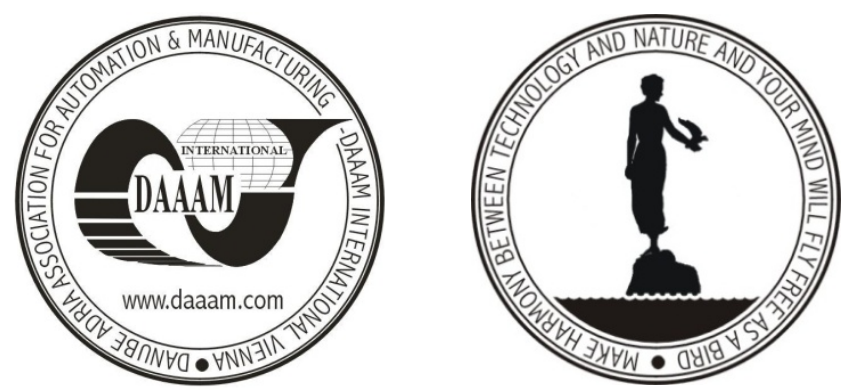

Authors' data: Eng. Celaya, A[inhoa $]^{*}$; Dr. PhD. Eng. Pujana, J[oseba]**; Prof. Lopez De Lacalle, L[uis] N[orberto]*; Eng. Rivero, A[sun]**; Dr. Campa, F[rancisco] J[avier]*; *University of the Basque Country, Department of Mechanical Engineering, University of the Basque Country UPV/EHU, Alameda de Urquijo, s/n, 48013, Bilbao, ES, **Fatronik, Department of Manufacturing Processses, Fundaci' on Fatronik, Paseo Mikeletegi 7, Parque Tecnologico, 20009, Donostia, ES, ainhoa.celaya@ehu.es, arivero@fatronik.com, fran.campa@ehu.es, implomal@ehu.es,jpujana@fatronik.com

This Publication has to be referred as: Celaya, A[inhoa]; Pujana, J[oseba]; Lopez De Lacalle, L[uis] N[orberto]; Rivero, A[sun] \& Campa, F[rancisco] J[avier] (2008). Improvement of Turning and Drilling by Ultrasonic Assistance, Chapter 18 in DAAAM International Scientific Book 2008, pp. 205-218, B. Katalinic (Ed.), Published by DAAAM International, ISBN 978-3-901509-66-7, ISSN 1726-9687, Vienna, Austria

DOI: $10.2507 /$ daaam.scibook.2008.18 